\title{
A four-legged snake from the Early Cretaceous of Gondwana
}

\author{
David M. Martill ${ }^{1}$, Helmut Tischlinger ${ }^{2}, \&$ Nicholas R. Longrich ${ }^{3}$
}

Snakes are a remarkably diverse and successful group today, but their evolutionary origins are obscure. The discovery of snakes with two legs has shed light on the transition from lizards to snakes, but no snake has been described with four limbs, and the ecology of early snakes is poorly known. We describe a four-limbed snake from the Early Cretaceous (Aptian) Crato Formation of Brazil. The snake has a serpentiform body plan with an elongate trunk, short tail, and large ventral scales suggesting characteristic serpentine locomotion, yet retains small, prehensile limbs. Skull and body proportions as well as reduced neural spines indicate fossorial adaptation, suggesting that snakes evolved from burrowing rather than marine ancestors. Hooked teeth, an intramandibular joint, a flexible spine capable of constricting prey, and the presence of vertebrate remains in the guts indicate that this species preyed on vertebrates, and that snakes made the transition to carnivory early in their history. The structure of the hind limbs suggests that they were adapted for grasping, either to seize prey or as claspers during mating. Together with a diverse fauna of basal snakes from the Cretaceous of South America, Africa, and India, this snake suggests that crown Serpentes originated in Gondwana.

${ }^{1}$ School of Earth and Environmental Sciences, University of Portsmouth, Portsmouth, PO1 3QL, UK.

${ }^{2}$ Tannenweg 16, 85134 Stammham, Germany. ${ }^{3}$ Department of Biology and Biochemistry, University of Bath, Claverton Down, Bath, BA2 7AY, UK 
Snakes are among the most diverse groups of tetrapods, with $>3,000$ extant species exploiting a remarkable range of niches(1). Snakes inhabit deserts and rainforests, mountains and oceans, and despite lacking limbs, employ an extraordinary range of locomotor styles, including crawling, burrowing, climbing, swimming, and even gliding(1). All snakes are predators, but they consume a wide range of prey, from insects to large mammals (1). This diversity is made possible by a specialized body plan, including an elongate body with reduced limbs, a flexible skull and ribs to swallow large prey(2), and a specialized forked tongue and vomeronasal organ to detect chemical gradients(1). The origins of this body plan remain unclear, however(1). One scenario holds that this unique body plan originated in a marine environment, while others argue that it results from adaptation for a fossorial lifestyle. New fossils(2-4), including snakes with hindlimbs (5, 6) have shed light on the lizard-snake transition, but no snake has been reported with four limbs. The ecology of early snakes is also uncertain. Although alethinophidians are primarily carnivorous (1), Typhlopidae and Anomalepididae, which are basal with respect to Alethinophidia (7-9), are insectivorous (1). This suggests that early snakes were insectivores, however adaptations for carnivory in stem snakes(2), suggest that carnivory may be primitive $(2,5)$.

Here, we report a fossil snake from the Early Cretaceous of Gondwana which sheds light on these issues. Tetrapodophis amplectus (gen. et sp. nov.) is distinguished from all known snakes in retaining four limbs, displaying a unique manual and pedal morphology with shortened metapodials, hyper-elongate and curved penultimate phalanges, and a digital formula of 2-3-3-3-3.

The fossil (Fig. 1) comes from the Nova Olinda member of the Early Cretaceous (Aptian) Crato Formation, Ceará, Brazil(10). The specimen is preserved on laminated limestone as part and counterpart. The matrix is typical of the Nova Olinda member of the Crato Formation in being composed of fine-grained, laminated micrite with elongated pellets on the surface of the slab representing coprolites of the fish Dastilbe. As is typical of Crato vertebrates, the skeleton is articulated and the bones are a translucent orangebrown color; soft tissues are also preserved. 
The snake affinities of Tetrapodophis are demonstrated by derived features of the skull, axial skeleton, limbs, integument and even behavior (* = snake autapomorphy). Snake-like features of the skull include a short rostrum, a long braincase, and a nasal descending lamina. The mandible is bowed, with a deep subdental ridge, and an intramandibular joint formed by a concave splenial cotyle contacting the angular, as in Dinilysia(11). Teeth exhibit the ophidian condition, being unicuspid and hooked, with expanded bases. Implantation is subacrodont implantation, with teeth separated by interdental ridges; replacement teeth are oriented subhorizontally*. Snake-like features of the axial skeleton include an elongate trunk with over 150 vertebrae*, zygosphenezygantrum articulations; an arched neural arch with posterolateral tuberosities*; short neural spines; haemal keels; large subcentral fossae/foramina, tubercular processes of the ribs, and lymphapophyses. The ilium is long and slender as in other snakes; the fibula is bowed as in Najash(5) and Simoliophiidae(12). Transverse belly scales* are preserved, and the presence of a vertebrate in the gut suggests a snake-like feeding strategy in which proportionately large prey are ingested whole. While many of these features occur in other long-bodied squamates, only snakes exhibit all of them, and many of these characters are uniquely ophidian.

Tetrapodophis exhibits a number of primitive characters, however. The nasal has a distinctive L-shape, as in Dinilysia(11) and Simolophiidae. The facial process of the maxilla is reduced compared to lizards but tall relative to crown snakes, as in Coniophis(2). The subdental ridge is shallow posteriorly, a primitive feature shared with Najash(5) and Coniophis(2). Unlike crown snakes, where a convex splenial condyle articulates with the angular, the splenial exhibits a concave cotyle, as in Dinilysia(11). Prezygapophyseal processes are absent as in other stem snakes; synapophyses are kidneyshaped, lacking the distinct condyle and planar cotyle of alethinophidians. Strikingly, Tetrapodophis retains reduced but apparently functional forelimbs and hindlimbs.

To test Tetrapodophis' ophidian affinities we used a morphological matrix $(13,14)$ to conduct four phylogenetic analyses: with and without molecular backbone constraint(8), and with equal and implied weighting(15). In each analysis, Tetrapodophis emerges as a basal snake. When a molecular backbone is used (Fig. 5), Tetrapodophis 
emerges as sister to Coniophis, and snakes emerge as sister to the Mosasauria, i.e. Pythonomorpha, as in a recent combined analysis(7).

As the only known four-legged snake, Tetrapodophis sheds light on the evolution of snakes from lizards. Tetrapodophis lacks aquatic adaptations (e.g. pachyostosis, long, laterally compressed tail) and instead exhibits features of fossorial snakes and lizards: a short rostrum and elongation of the postorbital skull, a long trunk and short tail $(16,17)$, short neural spines(18), and highly reduced $\operatorname{limbs}(16,17)$. Tetrapodophis therefore supports the hypothesis that snakes evolved from burrowing $(2,5,6)$, rather than marine(19) ancestors. While the current analysis suggests a sister-group relationship between Mosasauria and Serpentes, Cretaceous aquatic snakes (Simoliophiidae) are recovered nested within crown Serpentes, aquatic habits are therefore derived within snakes $(2,7)$.

Tetrapodophis also sheds light on the evolution of snake feeding. Tetrapodophis exhibits adaptations for carnivory, including recurved, claw-like teeth to seize large prey, and an intramandibular joint allowing the gape to expand to swallow large prey. Along with the presence of a vertebrate in the gut, these feature show that Tetrapodophis preyed on vertebrates. Similar adaptations occur in other early snakes(2,11), suggesting that snakes made the transition to carnivory early in their history, and that the insectivorous lifestyle of typhlopids and anomalolepidids is derived.

The structure of the spine may represent another such adaptation for carnivory. Elongate bodies and reduced limbs evolved many times among squamates $(13,17)$, occurring in burrowing and terrestrial forms(17), as well as aquatic mosasaurs. Yet snakes are unique among long-bodied squamates in having over 150 precaudal vertebrae. This permits extreme flexibility of the spinal column, such that the entire body can coil into tight loops. The fact that other long-bodied squamates lack this feature suggests that it is not related to locomotion. We propose that the increased number of trunk vertebrae may be an adaptation allowing the body to be used to constrict prey. Tetrapodophis exhibits both an increased number of precaudal vertebrae and a high degree of flexibility, with the body forming a tight coil anteriorly and a series of sinuous curves posteriorly, suggesting that constriction was developed even in the earliest snakes. 
The structure of the limbs may represent another predatory adaptation. The snakelike spine and reduced limbs of Tetrapodophis suggest that the animal engaged in characteristic serpentine locomotion, with the limbs playing little or no role in locomotion. However, the specialized structure of the limbs suggests that they were functional. Given Tetrapodophis' presumed fossorial habits, digging is a plausible function, but the limbs lack fossorial specializations. Instead, the manus and pes exhibit slender, isodactyl digits with hyper-elongate penultimate phalanges and abbreviated proximal phalanges. This suite of characters recalls the prehensile feet of animals such as scansorial birds, sloths $(20)$ and bats, suggesting a grasping or hooking function. Conceivably, the limbs could have functioned for grasping prey, or perhaps mates. Climbing is another possibility, although the low neural spines seem inconsistent with this function. Regardless, Tetrapodophis shows that after the initial evolution of serpentine locomotion, the limbs were repurposed for another function.

Finally, Tetrapodophis sheds light on the geographic origin of snakes. The Serpentes, Iguania, and Anguimorpha form the Toxicofera(7-9), with the oldest iguanian and anguimorph fossils coming from Laurasia(13). These patterns suggest the center of toxicoferan diversification is Laurasia, and that the ancestors of snakes probably originated there. The identification of possible stem ophidians from the Jurassic and Early Cretaceous of Laurasia(4) would support this hypothesis. However, the most basal divergences within crown Serpentes, including Anomalolepididae and Typhlopidae, Aniliidae and Tropidophiidae, are endemic to or originate in South America and Africa, hinting at Gondwana origins(1). Furthermore, during the middle Cretaceous, Gondwana was home to a diverse fauna of basal snakes, including Coniophiidae, Russellophiidae, Madtsoiidae(21), and Simoliophiidae(22) in the Cenomanian of Africa, the CenomanianTuronian Najash $(18,23)$ in South America, and now Tetrapodophis from the Aptian of South America. Snakes are far less diverse in the Cretaceous of Laurasia, with a single lineage appearing in the Cenomanian(24) of North America; alethinophidians do not appear until the Maastrichtian in North America(14) and Europe(25). These patterns suggest that the Serpentes represent an endemic Gondwanan radiation that saw limited dispersal to Laurasia during the Cretaceous. 
Snakes appear to have been part of a highly endemic herpetofauna that evolved in the Cretaceous in Gondwana. In this fauna, notosuchian crocodiles(26) and rhynchocephalians(27) played a major role, while squamates appear to have been less diverse and disparate than in Laurasia. The exception is the snakes, which radiated to produce small burrowers, large constrictors, and aquatic forms $(21,22)$. Much of this unique herpetofauna appears to have become extinct during the K-Pg extinction (Notosuchia) or was greatly reduced in diversity in the Cenozoic (Rhynchocephalia). Snakes, meanwhile, not only survived but became diverse and widespread in the Paleogene(14), perhaps in response to ecological release provided by the end-Cretaceous mass extinction(14).

\section{References and Notes}

1. H. W. Greene, Snakes: the Evolution of Mystery in Nature. (University of California Press, Berkeley, 1997), pp. 351.

2. N. R. Longrich, B.-A. S. Bhullar, J. A. Gauthier, A transitional snake from the Late Cretaceous period of North America. Nature 488, 205-208 (2012).

3. J. D. Scanlon, M. S. Y. Lee, The Pleistocene serpent Wonambi and the early evolution of snakes. Nature 403, 416-420 (2000).

4. M. W. Caldwell, R. L. Nydam, A. Palci, S. Apesteguía, The oldest known snakes from the Middle Jurassic-Lower Cretaceous provide insights on snake evolution. Nature communications 6, (2015).

5. S. Apesteguía, H. Zaher, A Cretaceous terrestrial snake with robust hindlimbs and a sacrum. Nature 440, 1037-1040 (2006).

6. E. Tchernov, O. Rieppel, H. Zaher, M. J. Polcyn, L. L. Jacobs, A Fossil Snake with Limbs. Science 287, 2010-2012 (2000).

7. T. W. Reeder et al., Integrated Analyses Resolve Conflicts over Squamate Reptile Phylogeny and Reveal Unexpected Placements for Fossil Taxa. PloS one 10, e0118199 (2015).

8. R. A. Pyron, F. T. Burbrink, J. J. Wiens, A phylogeny and revised classification of Squamata, including 4161 species of lizards and snakes. BMC evolutionary biology 13, 93 (2013).

9. J. J. Wiens et al., Resolving the phylogeny of lizards and snakes (Squamata) with extensive sampling of genes and species. Biology Letters 8, 1043-1046 (2012).

10. D. M. Martill, G. Bechly, R. F. Loveridge, The Crato Fossil Beds of Brazil. (Cambridge University Press, Cambridge, 2007).

11. H. Zaher, C. A. Scanferla, The skull of the Upper Cretaceous snake Dinilysia patagonica Smith-Woodward 1901, and its phylogenetic position revisited. Zoological Journal of the Linnean Society 164, 194-238 (2012).

12. M. S. Lee, M. W. Caldwell, Anatomy and relationships of Pachyrhachis problematicus, a primitive snake with hindlimbs. Philosophical Transactions of the Royal Society of London. B, Biological Sciences 353, 1521-1552 (1998). 
13. J. Gauthier, M. Kearney, J. A. Maisano, O. Rieppel, A. Behlke, Assembling the squamate tree of life: perspectives from the phenotype and the fossil record. Bulletin Yale Peabody Museum 53, 3-308 (2012).

14. N. R. Longrich, A.-B. S. Bhullar, J. Gauthier, Mass extinction of lizards and snakes at the Cretaceous-Paleogene boundary. Proceedings of the National Academy of Sciences 109, 21396--21401 (2012).

15. P. A. Goloboff, J. M. Carpenter, J. S. Arias, D. R. M. Esquivel, Weighting against homoplasy improves phylogenetic analysis of morphological data sets. Cladistics 24, 758-773 (2008).

16. J. J. Wiens, J. L. Slingluff, How lizards turn into snakes: a phylogenetic analysis of body-form evolution in anguid lizards. Evolution 55, 2303-2318 (2001).

17. J. J. Wiens, M. C. Brandley, T. W. Reeder, Why does a trait evolve multiple times within a clade? Repeated evolution of snakeline body form in squamate reptiles. Evolution 60, 123-141 (2006).

18. H. Zaher, S. Apesteguía, C. A. Scanferla, The anatomy of the Upper Cretaceous snake Najash rionegrina Apesteguía \& Zaher, 2006, and the evolution of limblessness in snakes. Zoological Journal of the Linnean Society 156, 801-826 (2009).

19. M. W. Caldwell, M. S. Y. Lee, A snake with legs from the marine Cretaceous of the Middle East. Nature 386, 705-709 (1997).

20. M. Hildebrand, G. Goslow, Analysis of Vertebrate Structure. (John Wiley and Sons, New York, 2001), pp. 635.

21. J.-C. Rage, C. Werner, Mid-Cretaceous (Cenomanian) snakes from Wadi Abu Hashim, Sudan: the earliest snake assemblage. Palaeontologia Africana 35, 85-110 (1999).

22. J.-C. Rage, D. B. Dutheil, Amphibians and squamates from the Cretaceous (Cenomanian) of Morocco A preliminary study, with description of a new genus of pipid frog. Palaeontographica Abteilung A, 1-22 (2008).

23. J.-C. Rage, A. M. Albino, Dinilysia patagonica (Reptilia, Serpentes): matériel vertébral additionel du Crétacé supérieur d' Argentine. Étude complémentaire des vertèbres, variations intraspécifiques et intracolumnaires. Neues Jahrbuch für Geologie und Paläontologie Monatschefte 1989, 433-447 (1989).

24. J. D. Gardner, R. L. Cifelli, A primitive snake from the Cretaceous of Utah. Special Papers in Palaeontology 60, 87-100 (1999).

25. J.-C. Rage, Les Madtsoiidae (Reptilia, Serpentes) du Crétacé supérieur d'Europe: témoins gondwaniens d'une dispersion transtéthysienne. Comptes rendus de l'Académie des sciences. Série 2. Sciences de la terre et des planètes 322, 603-608 (1996).

26. P. M. O'Connor et al., The evolution of mammal-like crocodyliforms in the Cretaceous Period of Gondwana. Nature 466, 748-751 (2010).

27. S. Apesteguía, F. E. Novas, Large Cretaceous sphenodontian from Patagonia provides insight into lepidosaur evolution in Gondwana. Nature 425, 609-612 (2003).

28. DM, NRL and HT designed and performed research; NRL performed the phylogenetic analysis, DM and NRL wrote the paper.

\section{ACKNOWLEDGMENTS}


Thanks to BASB Bhullar, J Gauthier, and JC Rage for discussions. The holotype is catalogued in the Museum Solnhofen as BMMS BK 2-2.

\section{SUPPLEMENTARY MATERIALS}

Figs S1-S7, Table S1

SOM Text

Character-taxon matrix

Constraint tree 

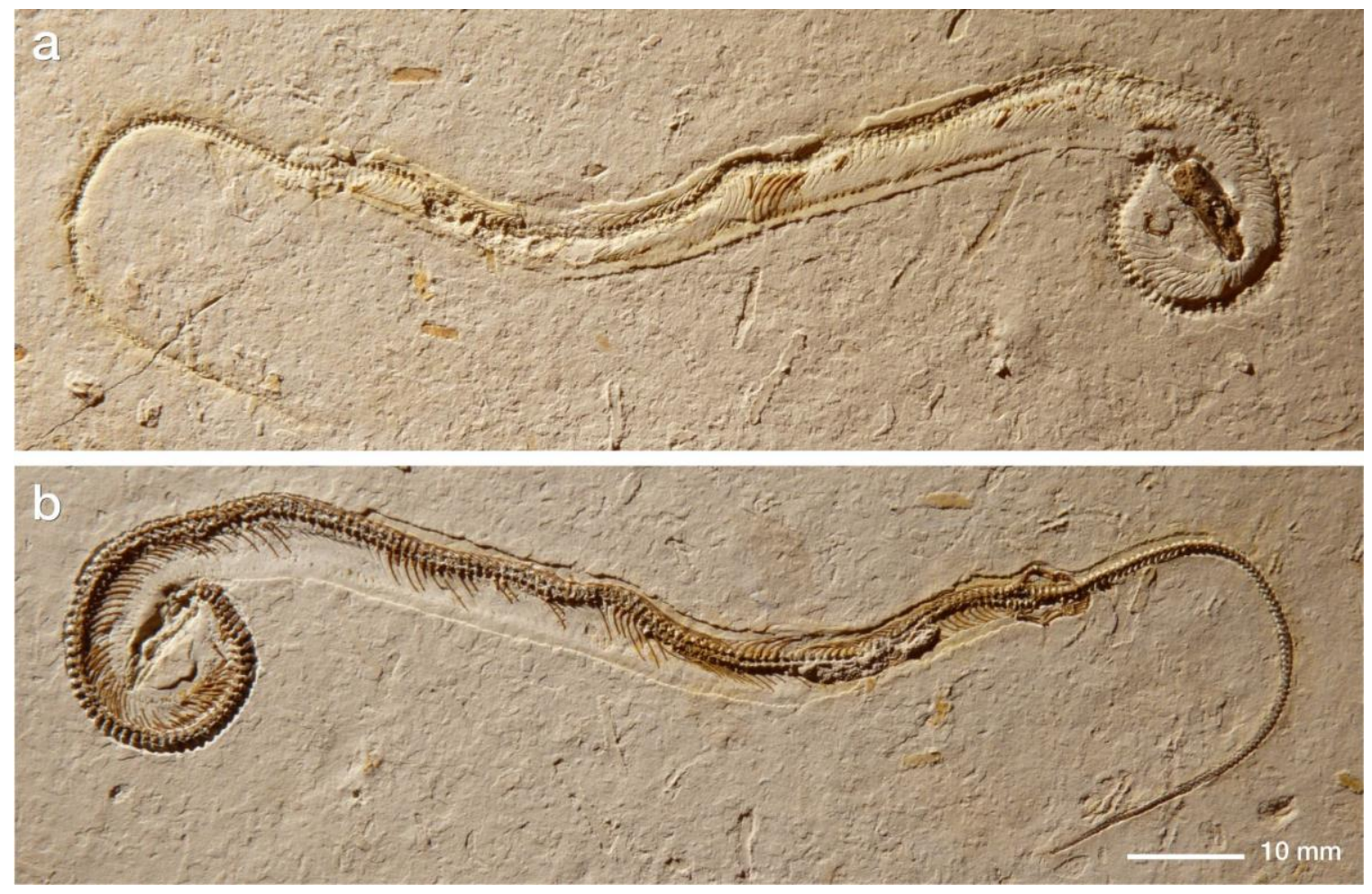

Fig. 1. Tetrapodophis amplectus, holotype part and counterpart. (A), counterpart, showing skull and skeleton impression, (B) main slab, showing skeleton and skull impression. 

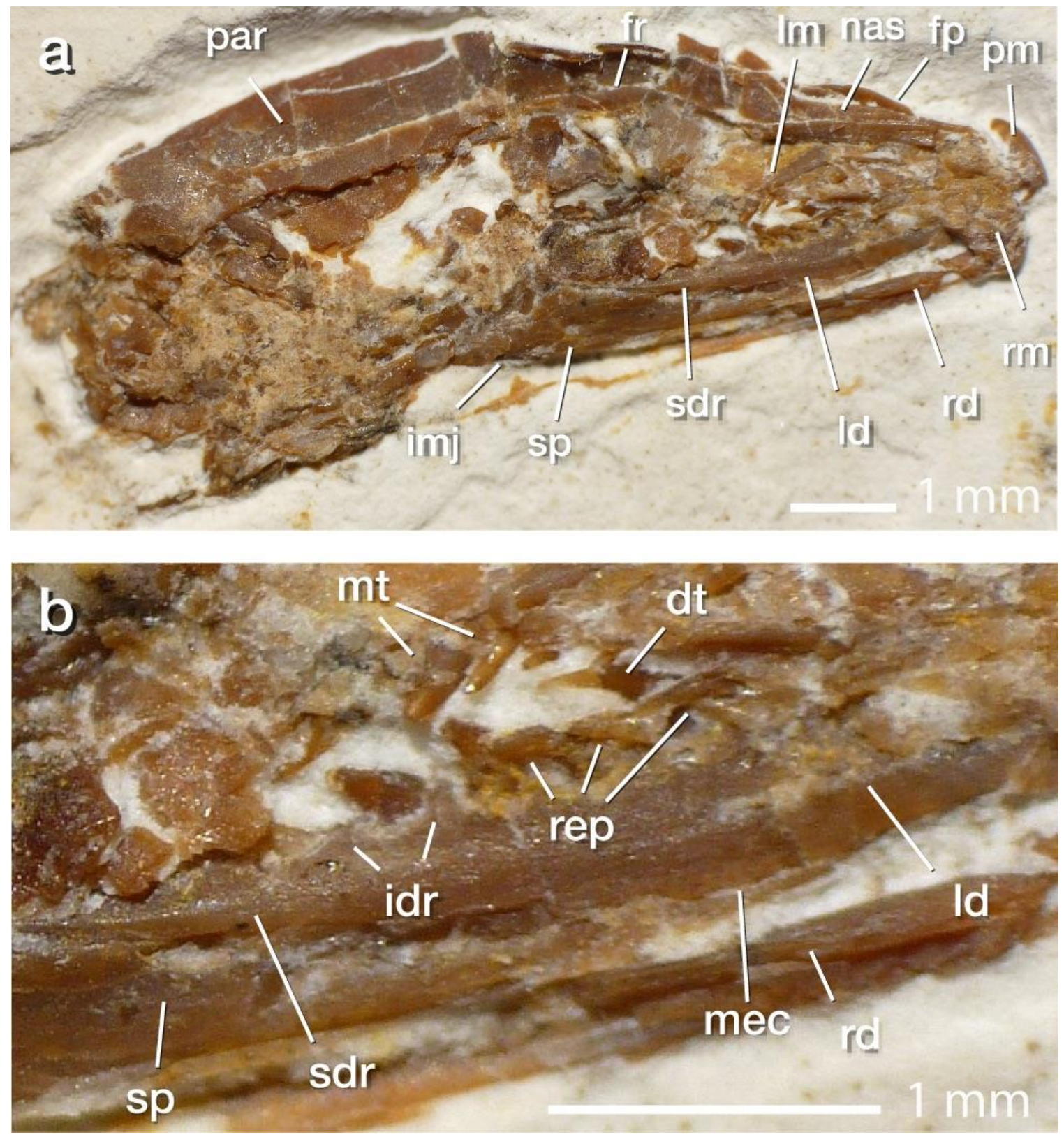

Fig. 2. Tetrapodophis amplectus, skull and jaws. (A) skull, (B) left mandible in medial view. Abbreviations: dt, dentary tooth; $\mathrm{fp}$, facial process of maxilla, $\mathrm{fr}$, frontal; Im, left maxilla, Id, left dentary; $\mathrm{mt}$, maxillary teeth; nas, nasal, par, parietal; pm, premaxilla; rd, right dentary; rd, right dentary; rt, replacement teeth; sdr, subdental ridge; sp, splenial. 

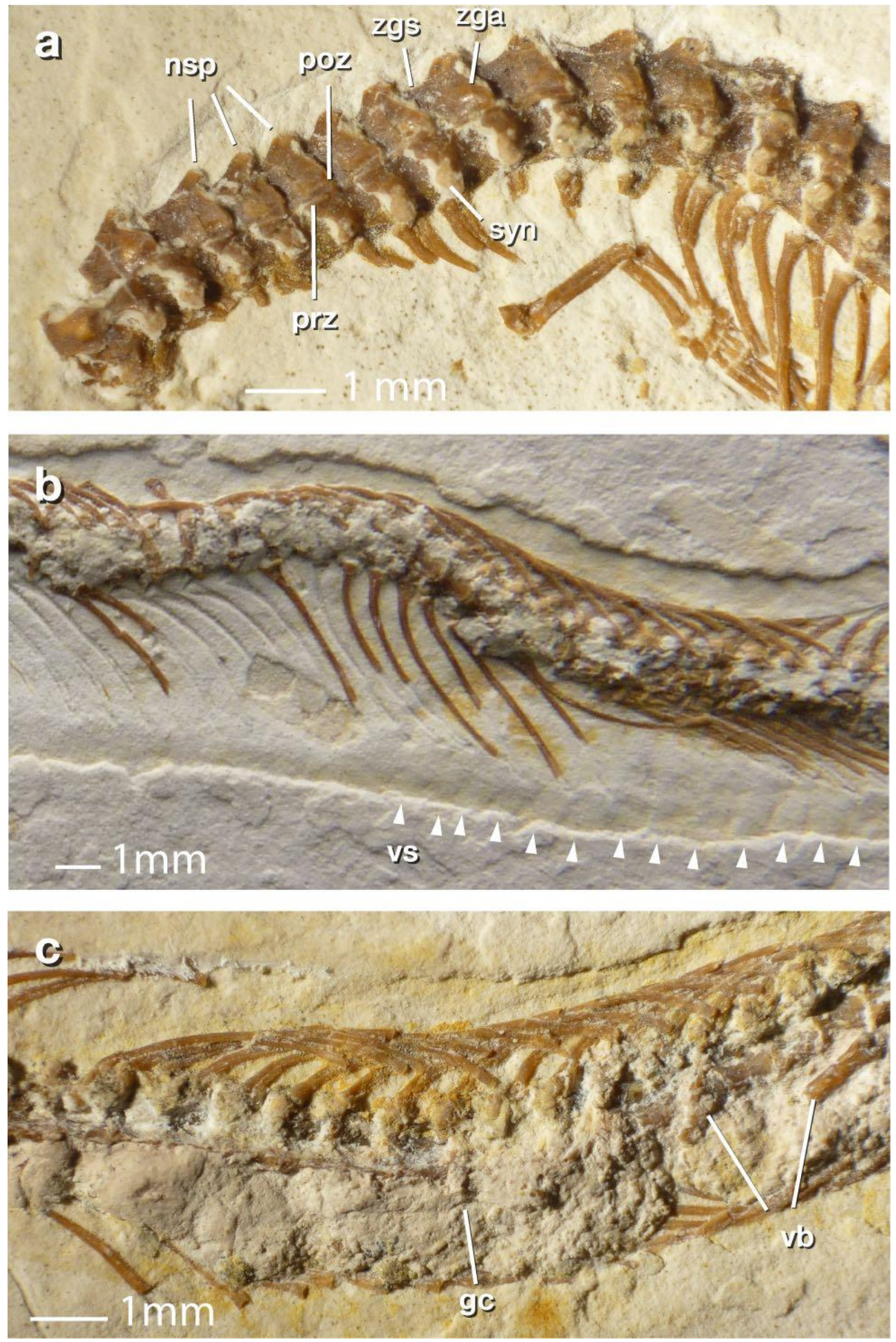

Fig. 3. Tetrapodophis amplectus axial column. (A) cervicals and anterior presacrals, (B) mid-thorax, showing ventral scales, (C) posterior thorax, showing gut contents. Abbreviations: gc, gut contents; nsp, neural spines; poz, postzygapophysis; prz, prezygapophysis; vb, vertebrate bone; vs, ventral scales; zga, zygantrum; zgs, zygosphene. 

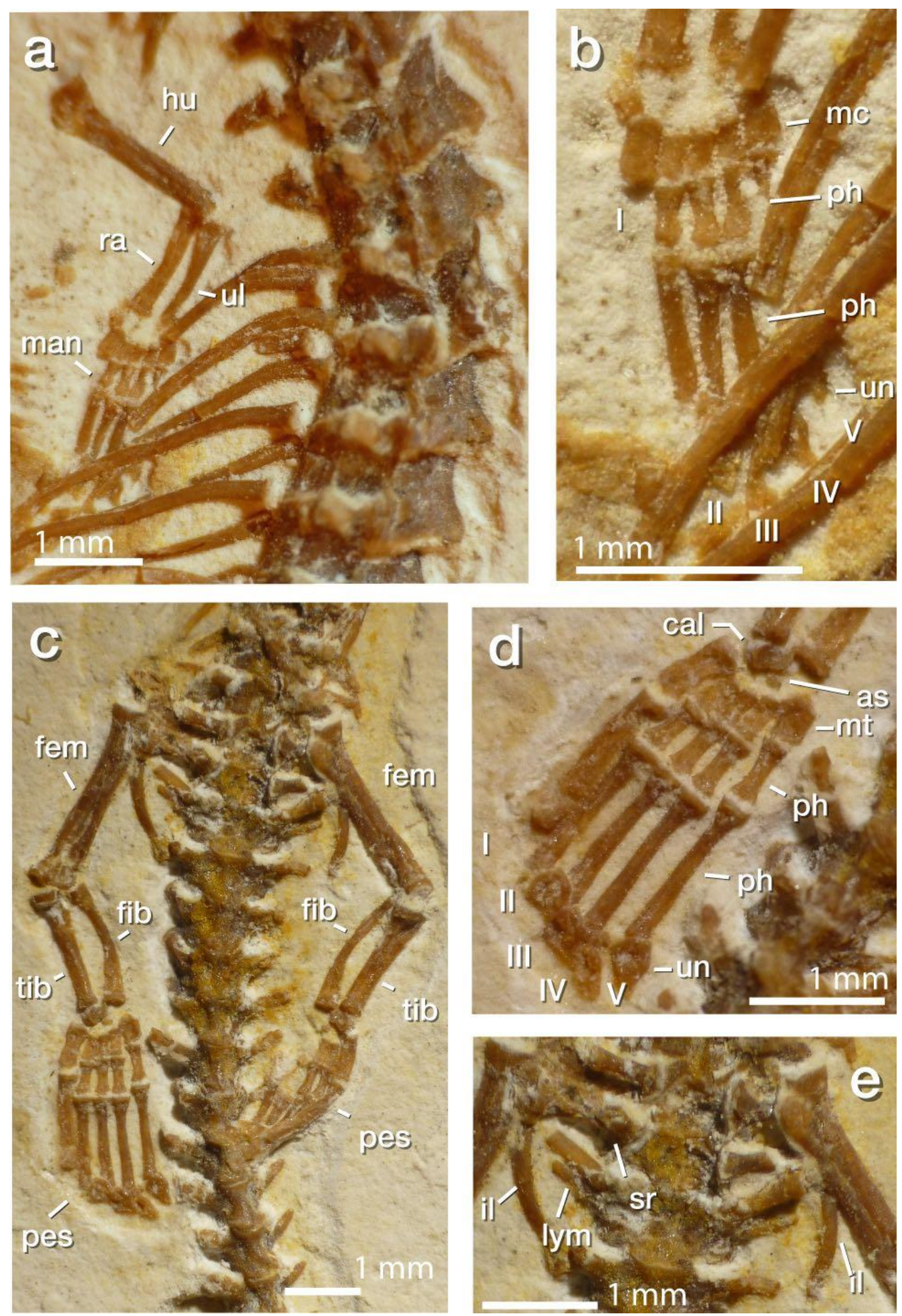

Fig. 4. Tetrapodophis amplectus appendicular morphology. (A) forelimb, (B) manus, (C) hindlimbs and pelvis, (D) pes, (D) pelvis. Abbreviations: fem, femur; fib, fibula; hu, humerus; il, ilium; lym, lymphapophysis, ma, manus; mc, metacarpal; mt, metatarsals; ph, phalanges; ra, radius; sr, sacral rib; tib, tibia; ul, ulna; un, ungual. 


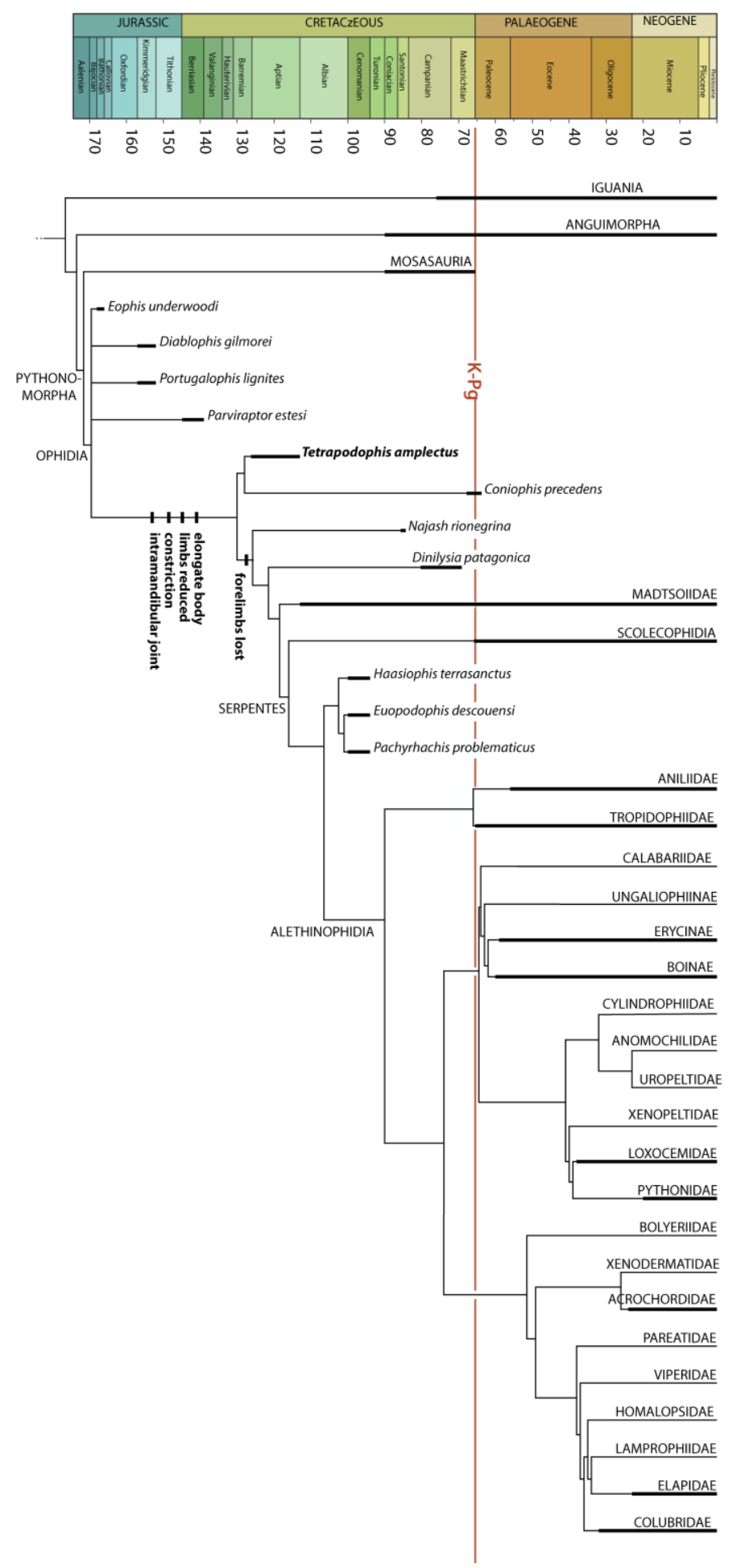

Fig. 5. Phylogenetic position of Tetrapodophis amplectus. Strict consensus of 85 most parsimonious trees found using implied weights and molecular constraint (see SI) for a matrix of 632 characters and 205 taxa. 